\title{
Sciendo
}

DOI 10.2478/afepuc-2020-0008

(C) Acta Facultatis Educationis Physicae Universitatis Comenianae 2020, 60(1): 94-104

\section{EXPLOSIVE STRENGTH OF LOWER LIMBS IN 10 - 12 YEARS OLD ATHLETES OF INDIVIDUAL SPORTS}

\author{
Daniela Leütterová ${ }^{1}$, Petra Tomková ${ }^{1}$, Dalibor Dzugas ${ }^{1}$, Peter Kačúr ${ }^{1}$, \\ Pablo Prieto Gonzalez ${ }^{2}$
}

${ }^{1}$ Faculty of Sports, University of Prešov, Slovakia

${ }^{2}$ Prince Sultan University, Saudi Arabia

\begin{abstract}
Summary. The aim of the study was to determine the levels of lower limb explosive strength of girls in different sport specialization. The sample consisted of 24 girls in aerobic gymnastics $(n=12)$ and athletic $(n=12)$ aged 10 to 12 years. To assess the levels of girls' lower limbs explosive strength, we administered the following tests: countermovement jump test, countermovement jump with free arms test, squat jump test, 10-seconds repetitive jumping test. Testing sessions took place in September 2019. To obtain data about the levels of lower limbs explosive strength, we recorded step height $(\mathrm{cm})$ and duration of the flight phase (s). Data about the lower limbs explosive strength were collected using the Optogait system for optical detection. We applied basic statistical characteristics, namely Student's ttest and multivariate linear regression. There were no significant differences between girls in aerobic gymnastics and athletics. We recorded better test results in the group of girl's athletes in the countermovement jump, countermovement jump with free arms and squat jump. In the group of girl's involved in aerobic gymnastics, we recorded better results in the 10-second repetitive vertical jumping and vertical jump strength. According to the collected data, we may conclude that the training process of the selected girls in terms of explosive strength development is significantly different. Girls involved in aerobic gymnastics showed a higher level of performance in the 10-second vertical jump, which results from the structure of sport specificity.
\end{abstract}

Key Words: jump ergometer, sensitive period, track and field, aerobic gymnastics, youth.

\section{Introduction}

Assessment of the current level of explosive strength of the lower limbs and vertical jump itself is an important factor of performance capacity. The level of vertical jump is assessed in almost all sports. 
Application of vertical jump diagnostic is frequently used in adult categories and many authors conclude that training process must be more effective of explosive strength. However, the studies of diagnosis of vertical jump of young athletes are relatively at an average level compared to the adult population (Hespanhol et. al. 2013).

In aerobic gymnastics, as well as in other sports, improving sports performance limits the level of fitness and coordination skills in interdependence with the rational technique of individual movements and difficulty elements. They are physiological mechanisms for building up motor habits, coordination abilities, physical abilities and movement skill as well as the anatomical and functional peculiarities, biomechanical characteristics of movements, pedagogical prerequisites and the difficulty elements' performance by optimum technique (Sergiev 2004; Perečinská et al. 2018).

The explosive strength in gymnastics sports shows itself in the major part of movements and elements performed by the gymnasts, particularly in the jumps, which are fundamental corporal movements in this sport. The training directed to the development of jumping capacity presents a large quantity of exercises, which aim to improve muscular strength in the lower limbs and therefore the impulsion capacity (Santos et. al. 2015).

According to Kyselovičová (2010) is explosive strength one of the most significant factors in aerobic gymnastics performance because gymnast must demonstrate intensive, dynamic and rhythmic sequences of high and low impact aerobics movements with difficulty elements. To compare strength in the active phase of take-off and height of the jump in maximal and during modified aerobic gymnastics routines is important to monitoring.

Explosive strength can be classified as a factor in the structure of sports performance, which directly affects performance itself (Šimonek et al. 2007). Explosive strength is characterized by several authors (Šimonek et al. 2007; Sedláček \& Lednický 2010; Feč \& Feč 2013) as the ability of the organism to generate maximum power in the shortest possible time. The explosive strength cannot be directly bounded, because it is also often associated with strength abilities for the strength component is a part of explosive strength. Besides strength component is in close relationship with coordination components based on optimal coordination of individual muscle groups involved in movement (Sedláček \& Lednický 2010). The most intensive development period (sensitive period) of explosive strength is approximately in 11-12 years old girls (Belej 2001), which correspond to our groups of tested girls. 


\section{Methods}

We diagnosed current level of the explosive strength of lower limbs in different sport specialization. The two samples consisted of 24 girls in all, involved in aerobic gymnastics $(\mathrm{n}=12)$ and athletic $(\mathrm{n}=12)$ aged from 10 to 12 years (born 2008 to 2010). A both groups were tested in September 2019. To compare the groups, we have used somatic measurements that may affect performance in the motor skills test:

- measurements of body height by anthropometer,

- measurements of body weight by digital weight (with a measurement deviation of $+/-0.1$ $\mathrm{kg})$.

To determine the level of explosive strength of the lower limbs we used following motor skills test:

\section{Countermovement jump (Fig. 1)}

Monitored parameter: height of jump (cm), time of flight jump (s).

Diagnostic device: OPTOGAIT- jump ergometer.

- participant must maintain hands on the hips for whole time of vertical jump.

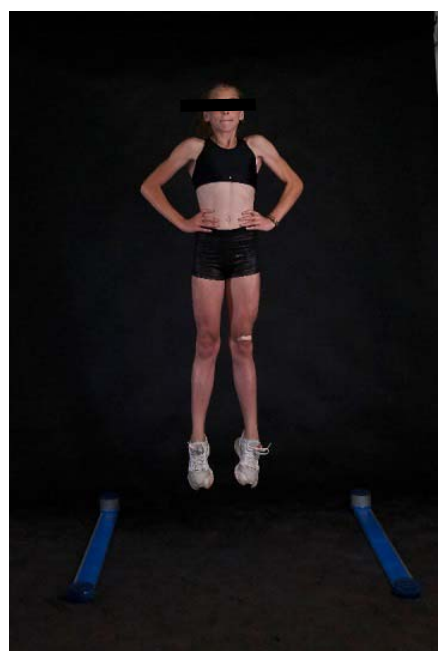

Figure 1

Countermovement jump

\section{Countermovement jump with free arms (Fig. 2)}

Monitored parameter: height of jump (cm), time of flight jump (s).

Diagnostic device: OPTOGAIT- jump ergometer.

- participant must maintain the arm swing as a potential benefit during vertical jump. 


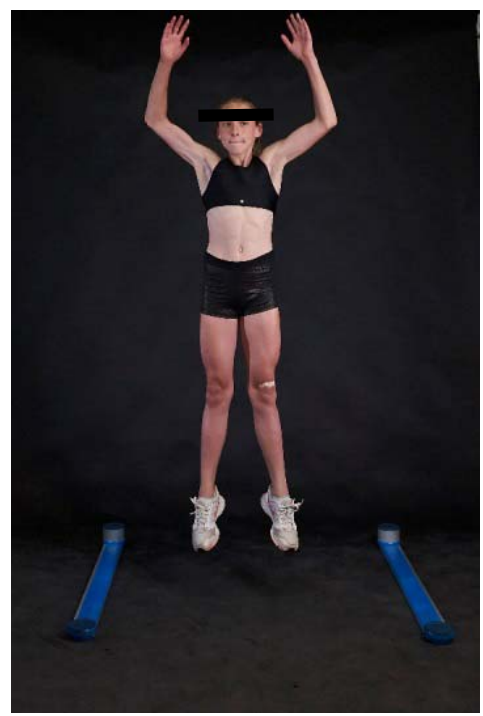

Figure 2

Countermovement jump with free arms

\section{Squat jump (Fig. 3)}

Monitored parameter: height of jump (cm), time of flight jump (s).

Diagnostic device: OPTOGAIT- jump ergometer.

- participant must maintain $90^{\circ}$ knee angle during squatting positions $1-2$ seconds.

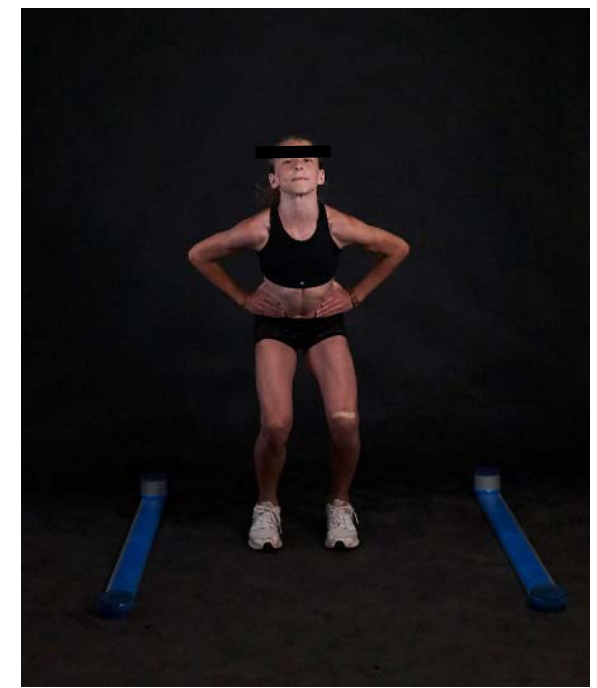

Figure 3

Squat jump

\section{10-seconds test of repetitive jumps (Fig. 4)}

Monitored parameter: height of jump (cm), time of flight jump (s).

Diagnostic device: OPTOGAIT- jump ergometer.

- participant must maintain hands on the hips during 10-second repetitive jumps, if not, the test must be repeated. 


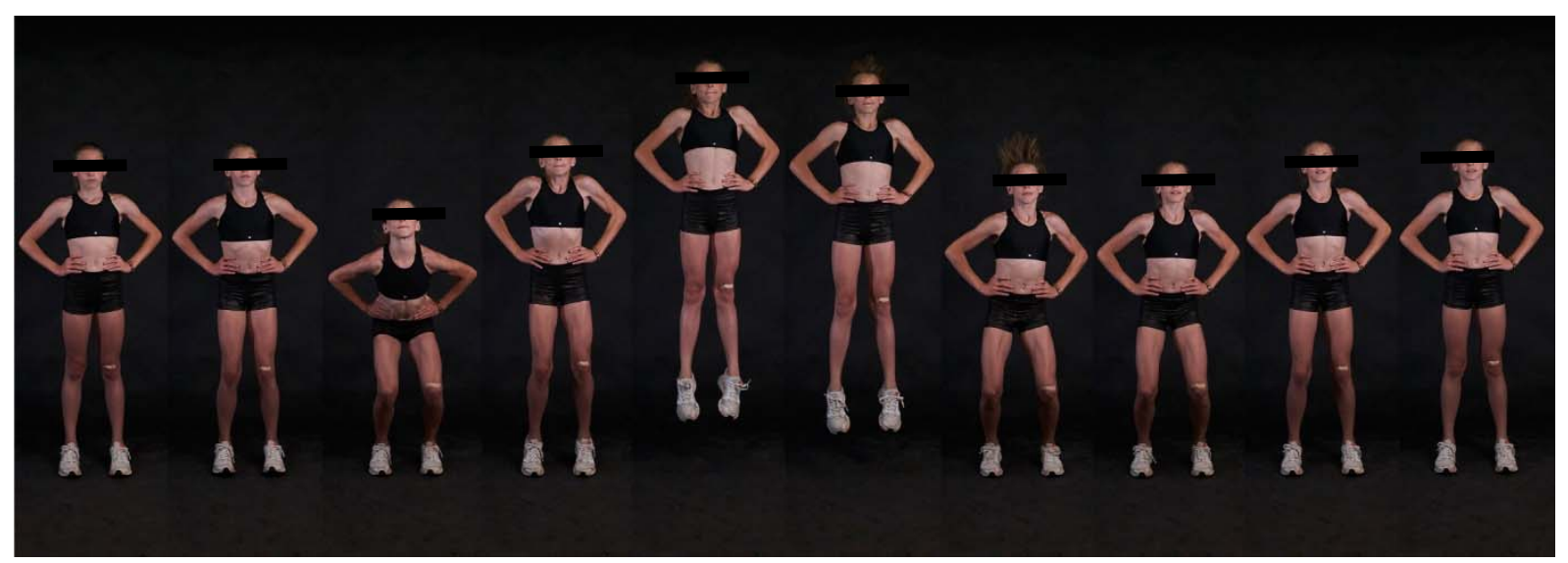

Figure 4

10-seconds test of repetitive jumps

For the data statistical processing we used the central tendency rate, median $(\mathrm{Me})$ due to the sample size. In addition to the basic statistical characteristics, we applied a statistical test to compare and confirm statistical significance between the monitored groups. We applied basic statistical characteristics, Student's t-test and multivariate linear regression to assess relationship between samples. We used the Shapiro-Wilk test to verify normality in the sample.

\section{Results and Discussion}

Based on the monitored indicators we reached individual conclusions. In comparing the body composition of girls with different sports specializations, we can state the following:

Table 1

Somatic measurement of experimental subjects

\begin{tabular}{|c|c|c|c|c|c|}
\hline & $\mathbf{n}$ & Average of age & $\begin{array}{c}\text { Body weight } \\
{[\mathbf{k g}]}\end{array}$ & $\begin{array}{c}\text { Body height } \\
{[\mathbf{c m}]}\end{array}$ & BMI \\
\hline Athletic & 12 & 11.7 & 34.6 & 145.1 & 16.5 \\
\hline Aerobic gymnastics & 12 & 10.9 & 34.8 & 147.7 & 16.1 \\
\hline
\end{tabular}

In Table 1 we recorded the values of the monitored somatic indicators of both groups in individual sports. In both research samples there were the same number of 12 girls, which we considered as low. Based on the low sample size, we used the median (Me) of the basic statistical characteristics, which represents $\mathrm{Me}=11.7$ years at the age of athletes. Aerobic competitors were 0.8 years younger than athletic competitors. In comparison of body height, we noticed a difference of 2.6 centimeters, in favor of aerobic competitors. Based on the available sources aerobic competitors, along with girls with specialization on gymnastics, achieve on average lower body height values than girls with other sports specializations 
(Mineva 2014). However, it was not confirmed in our case. When comparing the monitored groups, namely from the measurements of girls' body height, the claim (Mineva 2014) is not confirmed. In comparison of the monitored groups and the monitored body weight indicator, we can find a difference of $0.2 \mathrm{~kg}$ in favor of aerobic competitors. The body mass index (BMI) is in athletes group at the level of 16.5 that we evaluate positively and we expected results to be in the norm in both monitored groups. Aerobic competitors achieved almost identical level of monitored body composition index compared to girls with athletic specialization (Table 1).

Table 2

Body compositions measurement of experimental subjects

\begin{tabular}{|c|c|c|c|}
\hline & $\begin{array}{c}\text { Muscle mass } \\
{[\mathbf{k g}]}\end{array}$ & $\begin{array}{c}\text { Fat mass } \\
{[\mathbf{k g}]}\end{array}$ & $\begin{array}{c}\text { Visceral fat mass } \\
{\left[\mathbf{c m}^{\mathbf{2}}\right]}\end{array}$ \\
\hline Athletic & 15.4 & 4.8 & 14.6 \\
\hline Aerobic gymnastics & 15.6 & 4.9 & 19.2 \\
\hline
\end{tabular}

The body composition of the both groups is presented in Table 2. The most important indicator of the body composition of our observation is the muscle mass indicator. The total muscle mass ratio was recorded in athletes, which was 0.2 kilograms lower compared to aerobics counterparts. Comparing visceral fat disproportion, we conclude that athletes performed better with a difference of $4.6 \mathrm{~cm}^{2}$ than aerobic competitors. Considering body fat mass, athletes reached 0.1 kilograms' higher value compared to aerobic competitors.

The indicators presented in Tables 1 and 2 were selected intentionally, with the aim of monitoring the statistical causality in performance of each test items focused on the level of explosive strength of the lower limbs. After obtaining the variables we assumed causality with the results of individual tests. Subsequently, we found out the relationship between the jumps height and series of variables that seemed to be the most important in explaining the variations in our research. The t-test showed the significance of the regression as the $p$ value came below the 5\% significance level $(\mathrm{p}<0.05)$. During the linear regression calculations, we followed the sequence of regression specificities.

When comparing individual tests that focus on the explosiveness of lower limbs between athletes and aerobic competitors, we found out whether the factor of sport selection at a young age plays a statistically different role in physical ability. With significantly different results in height jumps, we would get a $p$ value that would confirm the significance of the difference in performance. The p-values obtained are recorded in Table 3. 
Table 3

Results of countermovement jump

\begin{tabular}{|c|c|c|c|c|}
\hline \multirow{2}{*}{} & \multicolumn{2}{|c|}{ Countermovement jump } & \multicolumn{2}{c|}{ Countermovement jump with free arms } \\
\cline { 2 - 5 } & $\begin{array}{c}\text { Time of flight } \\
{[\mathbf{s}]}\end{array}$ & $\begin{array}{c}\text { Height of jump } \\
{[\mathbf{c m}]}\end{array}$ & $\begin{array}{c}\text { Time of flight } \\
\text { [s] }\end{array}$ & $\begin{array}{c}\text { Height of jump } \\
{[\mathbf{c m}]}\end{array}$ \\
\hline Athletic & 0.426 & 22.25 & 0.472 & 27.45 \\
\hline Aerobic gymnastics & 0.425 & 22.10 & 0.465 & 26.45 \\
\hline $\begin{array}{c}\text { P-value } \\
\text { Height of jump }\end{array}$ & \multicolumn{2}{|c|}{0.983} & & 0.904 \\
\hline
\end{tabular}

Table 4 presents the results of the participants in countermovement jump test and countermovement jump with free arms test. As Vavák (2014) states, the influence and potential of arm swing is an essential factor in a vertical jump. When practicing the swing of the arms, there is a sum of the acting forces in the direction of jump, where, in addition to the lower limbs, the upper part of the body, namely the arms, is significantly involved in the monitored performance. Moreover, Sedláček and Lednický (2010) point out that other segments and muscle groups of the body, such as the upper limbs and torso muscles are also involved in the vertical jump. Comparing research groups, we concluded in countermovement jump test that the achieved results did not show a significant difference in the vertical jump performance. The difference was recorded at a level of 0.15 centimeter at the height of the jump and 0.001 seconds at the time of the flight phase of the jump. The test results did not show a statistically significant difference between the observed groups $(p<0.05)$ in the jump height indicator.

In the calculation of linear regression, we finally obtained the significance of one variable, namely muscle mass, which reached $p$ value of 0.0004 , which we consider as statistically significant. The other monitored physical parameters were marked as noninfluencing and statistically insignificant in the maximum vertical jump test item.

In the countermovement jump with free arms test, we noticed better results of athletics competitors compared to aerobic competitors. Athletes achieved better performance results in the test item by $1 \mathrm{~cm}$. We believe that the observed difference was influenced by the fact that athletes practiced the training and the development of the high jump in the training process. Moreover, the practicing of arm swinging exercises in the vertical plane during the training process also influenced and distorted the test results. Aerobic competitors use arm swing in 
the training process, but with variations in the direction and height of arm movement within aerobics exercises variations and exercises shapes difficulties. We also decided to compare the performance of the girls by applying different exercises that could affect the results of the test item in both research groups.

From the statistical point of view, the significance of the performance in comparison of both monitored groups was not confirmed. Comparing the linear regression of the groups, we can conclude the relationship between the muscle mass $(p=0.007)$ of the girls and the visceral fat $(\mathrm{p}=0.001)$, which was also confirmed statistically and can be considered as a significant relationship.

Table 4

Results of squat jump and 10-second jump test

\begin{tabular}{|c|c|c|c|c|c|}
\hline & \multicolumn{2}{|c|}{ Squat jump } & \multicolumn{2}{|c|}{ 10-second test of vertical jumps } & \multirow{2}{*}{$\begin{array}{c}\text { Power of } \\
\text { jump } \\
{[\mathbf{W} / \mathbf{k g}]}\end{array}$} \\
\hline & $\begin{array}{c}\text { Time of flight } \\
{[\mathrm{s}]}\end{array}$ & $\begin{array}{c}\text { Height of jump } \\
{[\mathrm{cm}]}\end{array}$ & $\begin{array}{c}\text { Time of flight } \\
{[\mathrm{s}]}\end{array}$ & $\begin{array}{c}\text { Height of jump } \\
{[\mathrm{cm}]}\end{array}$ & \\
\hline Athletic & 0.421 & 21.75 & 0.408 & 20.46 & 23.46 \\
\hline $\begin{array}{c}\text { Aerobic } \\
\text { gymnastics }\end{array}$ & 0.418 & 21.40 & 0.424 & 21.9 & 26.53 \\
\hline P-value & \multicolumn{2}{|c|}{0.952} & \multicolumn{2}{|c|}{0.922} & 0.879 \\
\hline
\end{tabular}

Results in Table 5 indicate that in a vertical jump performed from the squat starting position athletics competitors showed a higher performance by $0.35 \mathrm{~cm}$ compared to aerobic competitors. When comparing the length of the flight phase, this is a 0.03 second difference. In verifying the significance of the results, we conclude that the test item of a squat jump is not statistically significant in comparison to the monitored groups of girls of different sports specializations. We reaffirm the relationship between the height of the jump and the muscle mass of the girls at $p<0.00015$ and the relationship to the visceral fat at the $p<0.02$. The data obtained about the variables relationships are statistically significant, which we consider to be very important.

We found out a significant difference in the vertical jumps for 10 -seconds test compared to the basic statistical characteristics. Comparing the jumps, the aerobic competitors showed higher measured values by $1.44 \mathrm{~cm}$, which is directly proportional to the indicator of the flight phase of the jump, namely $0.016 \mathrm{~s}$. Compared to athletics competitors, aerobic competitors exert a greater force in the active phase of vertical jumps by $3.07 \mathrm{~W} / \mathrm{kg}$. The records reflect the need for long-term dynamic movement of aerobic competitors in aerobic ties and difficulty elements. The reason may be that gymnastic routines contain more 
dynamic elements and therefore gymnasts should be provided a higher level of jump capabilities compared to the group of athletics (Mlsnová, Luptaková 2017).

In conclusion, we can point out the relationship between vertical jumps in 10-seconds and the muscle mass of girls at $\mathrm{p}<0.02$, which we also assumed.

\section{Conclusion}

During the testing we did not gain sufficient evidence against the null hypothesis, which meant equality of observations at the measured values. The result obtained by Student's T-test on the significance level $p \leq 0.05$, was not statistically significant in the comparisons between research groups. Athletes and aerobic competitors do not significantly differ in vertical jump performance, meaning that performances is not visibly affected by specific and heterogeneous training processes in selected sports. Statistical significance was also assumed by looking at relatively identical research samples characteristics and performance in individual test items.

By testing individual performances in test items with selected variables (age, body weight, body height, muscle mass, fat component, visceral fat) we obtained results using linear regression. Significant relationship in the test items like vertical jump, vertical armjump, squat vertical jump and vertical jumps for 10 -seconds is manifested with the variable muscle mass. Muscle mass showed the most significant dependence on the explosive strength of the lower limbs. It is interesting to note that variables such as body height, body weight and fat component did not appear to be limiting factors in the explosive strength of the lower limbs. Visceral fat was the second factor to confirm in vertical arm-jump and squat vertical jump.

During the analysis of the results we came up with an absent variable that can influence the individual results of the competitors. An important variable can be the sports age or previous sports activity. In conclusion, with the possibility of re-diagnosing the explosiveness of the lower limbs, we would recommend focusing on the muscle distribution of the lower limbs, not just the total muscle mass. We assume that the muscle distribution of the lower limbs has an impact on the height of the flight phase in different jumping techniques in the individual test items and consequently a direct proportion in the height of the vertical jump.

Considering the measured results, we assume that the training processes in both sports indicate a balanced general movement base. This is based on results in which we do not 
observe extreme deviations in the explosive strength of the lower limbs and in the basic anthropometric characteristics.

\section{References}

1. BELEJ, M., 2001. Motorické učenie. Slovenská vedecká spoločnost' pre telesnú výchovu a šport. Prešov: Grafotlač. ISBN 80-8069-041-8.

2. HESPANHOL, J. E., M. ARRUDA, M. A. BOLAÑOS \& R. L. SILVA, 2013. Sensitivity and specificity of the strength performance diagnostic by different vertical jump tests in soccer and volleyball at puberty. In: Revista Brasileira de medicina do esporte. 19 (5), 367-370. ISSN 1517-8692.

3. FEČ, R. \& FEČ, K., 2013. Teória a didaktika športového tréningu. Košice: Univerzita P.J. Šafárika, Ústav telesnej výchovy a športu. ISBN 978-80-8152-087-7.

4. KYSELOVIČOVÁ, O. \& E. ZEMKOVÁ, 2010. Modified aerobic gymnastics routines in comperison with laboratory testing of maximal jumps. In: Sport Scientific and Practical Aspects. 7(1), pp. 37-40. ISSN 1840-4413.

5. KRAEMER, W. \& R. NEWTON, 1994. Training for improved vertical jump. In: Sports Science Exchange. 7(6), pp. 1-12.

6. MINEVA, M., 2014, Somatotype of elite aerobic gymnastics competitors. In: Scientific research in aerobic gymnastics, summary 2010 - 2014, 1 st eds., Fédération internationale de gymnastique, pp. 27-29.

7. MLSNOVÁ, G. \& J. LUPTÁKOVÁ, 2017. Influence of plyometrics on jump capabilities in technical and aesthetical sports. In: Acta facultatis educationis physicae universitatis comenianae. 57(1), pp. 76 -88. ISSN 0520-7371.

8. PEREČINSKÁ, K., et al., 2018. Implementácia nových tematických celkov gymnastickoaerobikových športov $v$ rámci výchovno-vzdelávacieho programu na školách a vo vol’nočasových aktivitách [online]. Prešov: Prešovská univerzita Fakulta športu v Prešove. Multimediálna elektronická učebnica [DVD-ROM]. Accessibile from:. http://videoportal.fhpv.unipo.sk/sportaerobik/. ISBN 978-80-555-2101-5.

9. SANTOS, A., E. Lebre \& L. Carvalho, 2015. Explosive power of lower limbs in rhythmic gymnastics athletes in different competitive levels. In: Revista brasileira de educação física e esporte. 30(1), pp. 41-50. ISSN 1807-5509. 
10. SEDLÁČEK, J. \& A. LEDNICKÝ, 2010. Kondičná atletická príprava. Bratislava: Slovenská vedecká spoločnost' pre telesnú výchovu a šport. 167 s. ISBN 978-80-8907534-8.

11. SERGIEV, G., 2004. Sports Aerobics: Technique of Execution and Training Methods of Difficulty Elements. Sofia: Bins. ISBN 9548017245.

12. ŠIMONEK, J., L. DOLEŽALOVÁ. \& A. LEDNICKÝ, 2007. Rozvoj výbušnej sily dolných končatín v športe. Bratislava: Slovenská vedecká spoločnost' pre telesnú výchovu. ISBN 978-80-89075-32-4.

13. VAVÁK, M., 2014. Vplyv švihu paží na vybrané parametre vertikálneho výskoku volejbalistiek. In: Telesná výchova a šport. 24(2), pp. 33-38. ISSN 1335-2245. 